\title{
Malacofauna of the Holocene tufa in the valley of the Ociemny Stream (Pieniny Mts., southern Poland)
}

\author{
Witold Paweł Alexandrowicz \\ AGH University of Science and Technology, Faculty of Geology, Geophysics and Environmental Protection, Department \\ of General Geology and Geotourism; al. A. Mickiewicza 30, 30-059 Krakow, Poland; e-mail: wpalex@geol.agh.edu.pl \\ (c) 2017 Authors. This is an open access publication, which can be used, distributed and reproduced in any medium according \\ to the Creative Commons CC-BY 4.0 License requiring that the original work has been properly cited.
}

Received: 2017-02-13; accepted: 2017-03-23

\begin{abstract}
A rich molluscan fauna was found in the outcrop of slope sediments and calcareous tufas in the valley of the Ociemny Stream in the Pieniny Mts. The malacological sequence identified there represents the entire Holocene, but it contains several stratigraphical gaps. From this viewpoint, it is a unique finding within the area studied. In nine samples, 11,000 specimens of 71 species of molluscs were identified. The ecological and zoogeographical diversity of the composition and structure enabled the separation of three faunistic assemblages. The oldest assemblage (with Discus ruderatus) corresponds with the cold period of the Early Holocene and represents shadowed habitats overgrown with the coniferous forests of the taiga type. Its characteristic feature is the presence of glacial relics (e.g. Vertigo genesii and Vertigo geyeri). The other younger fauna (with Discus perspectivus) is typical of the humid and warm climate of the Atlantic Phase. It is characteristic of the habitats of mixed and deciduous forests. Numerous Balkan and Mediterranean thermophilous forms appear in this assemblage. The youngest malacoenosis (with Bithynella austriaca) is typical for the historical times. The particular intervals containing molluscan fauna are separated by gaps corresponding to the erosion phases. Because of the land relief in the valley of the Ociemny Stream, which is not conducive to the development of human economy, no marked anthropogenic deforestation occurs.
\end{abstract}

Keywords: calcareous tufa, malacofauna, environmental changes, Holocene, Pieniny Mountains

\section{INTRODUCTION}

Calcareous tufas occur commonly within the Pieniny Mts. Their deposition is favoured by high content of calcium carbonate in underlying bedrocks and in slope covers. The calcareous tufas are most often found near springs, waterfalls, and at the feet of rock walls. These sediments are formed by way of the precipitation of calcium carbonate from water, resulting from changes in pressure and temperature, and also as an effect of the activities of plants. They show great lithological diversity ranging from hard, lithified travertines, through loose-grained tufas, to as far as dust varieties and calcareous muds. Detailed classifications of calcareous tufas, taking into account their lithological, genetic, and morphological features were presented by many authors (e.g. Chafetz \& Folk 1984, Pedley 1990, 2009, Goudie et al. 1993, Pentecost 1995). The high content of calcium carbonate and the generally quiet course of sedimentation in calcareous tufas facilitates the preservation of molluscan shells. Their analysis enables reconstructions of the conditions in which the deposits were formed, as well as of biotic and abiotic conditions prevailing during the deposition.

The multi-year studies of the malacofauna in calcareous tufas carried out in the Pieniny Mts. permitted the characterization of several dozen locations of these sediments (S.W. Alexandrowicz 1993, 
W.P. Alexandrowicz 2004, 2010, W.P. Alexandrowicz et al. 2016). The majority of them are tufas precipitated in spring zones or at the bases of rock walls. Usually, they span over short periods of time - several hundred of most recent years (W.P. Alexandrowicz 2004, 2010, W.P. Alexandrowicz et al. 2016). In the Pieniny Mts., the tufas representing the older part of Holocene are rare. One of such uncommon profiles is the outcrop in the valley of the Ociemny Stream.

The Ociemny Stream is a minor left-bank tributary to the Dunajec River. Its mouth is situated approx. $700 \mathrm{~m}$ southeast of the centre of the town of Krościenko along the road leaving to Zawiasy Rock (Fig. 1). The outcrop itself is situated in the central portion of the valley, approx. $400 \mathrm{~m}$ above its mouth to the Dunajec River (GPS: $49^{\circ} 25^{\prime} 31^{\prime \prime N}$; $20^{\circ} 26^{\prime} 02^{\prime \prime} \mathrm{E}$ ). In the section, the Ociemny Stream runs across limestones classified as Upper Jurassic and Lower Cretaceous periods of the Branisko succession (e.g. Birkenmajer 1977). The tufas form a low terrace, reaching $1.5 \mathrm{~m}$ above the contemporary streambed. In the lower part of the exposed profile of this terrace, brown loams with angular limestone debris ( $25 \mathrm{~cm}$ thick) can be distinguished. Their top is uneven and covered by a several-centimetre thick layer of sand with limestone gravels. Above the sands, there is a $5-8 \mathrm{~cm}$ thick layer of hard very porous travertines. Still higher, yellowish silty tufas are exposed (approx. $30 \mathrm{~cm}$ thick) covered next by sands with limestone gravels. The border between tufa and sands is uneven. Above the sands, there is a second insertion of hard travertines (10-12 cm thick) on which are loose grained and silty, white, and grey calcareous tufas (total approx. $70 \mathrm{~cm}$ thick). The whole of the profile is topped by a thin layer of contemporary soil (Fig. 2). In floor clays, as well as in grained and silty tufas, high numbers of molluscan shells were found, providing the basis for the reconstruction of the environment of the deposition of these sediments.

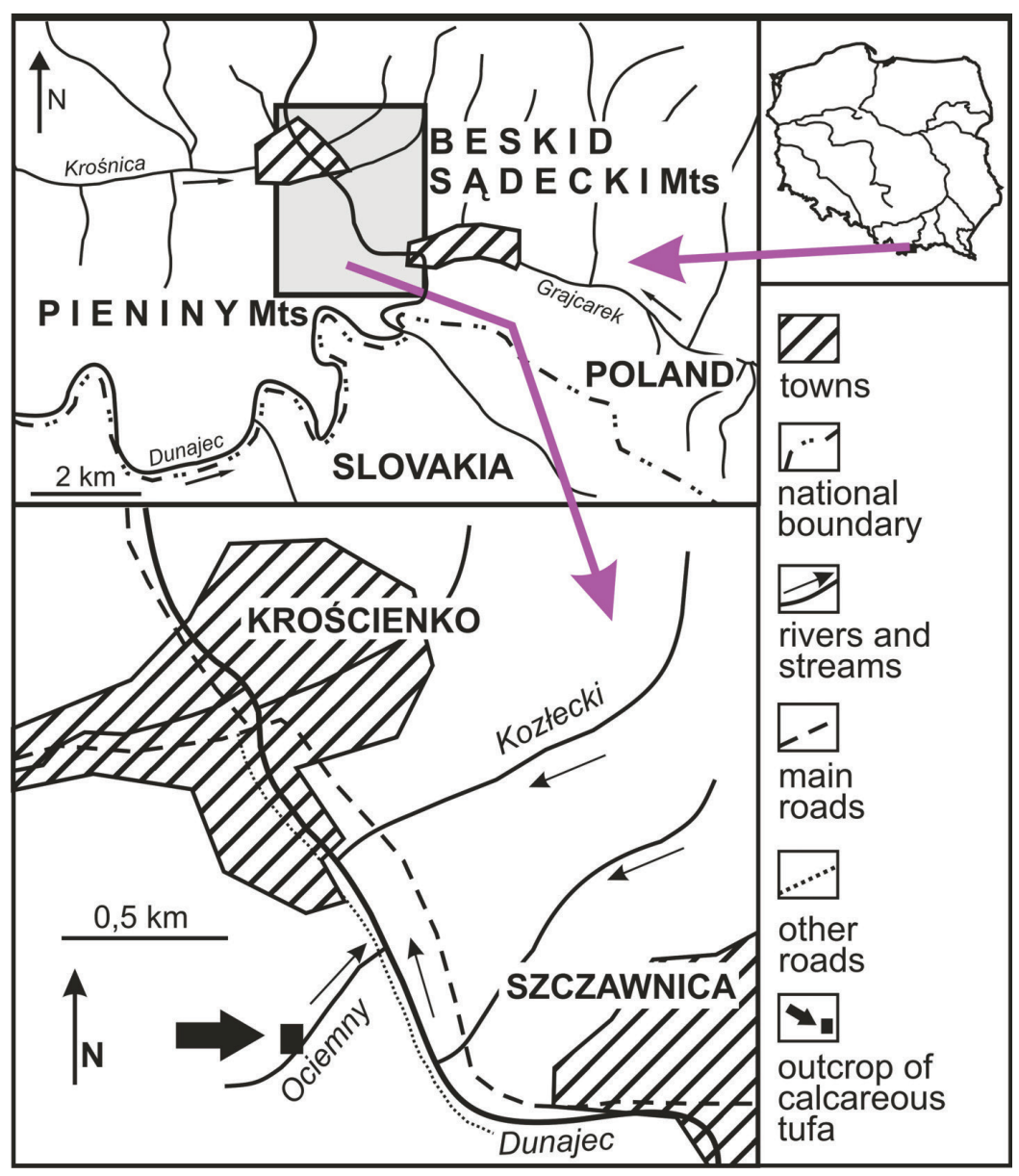

Fig. 1. Location of the profile of calcareous tufa in the Ociemny Stream valley 


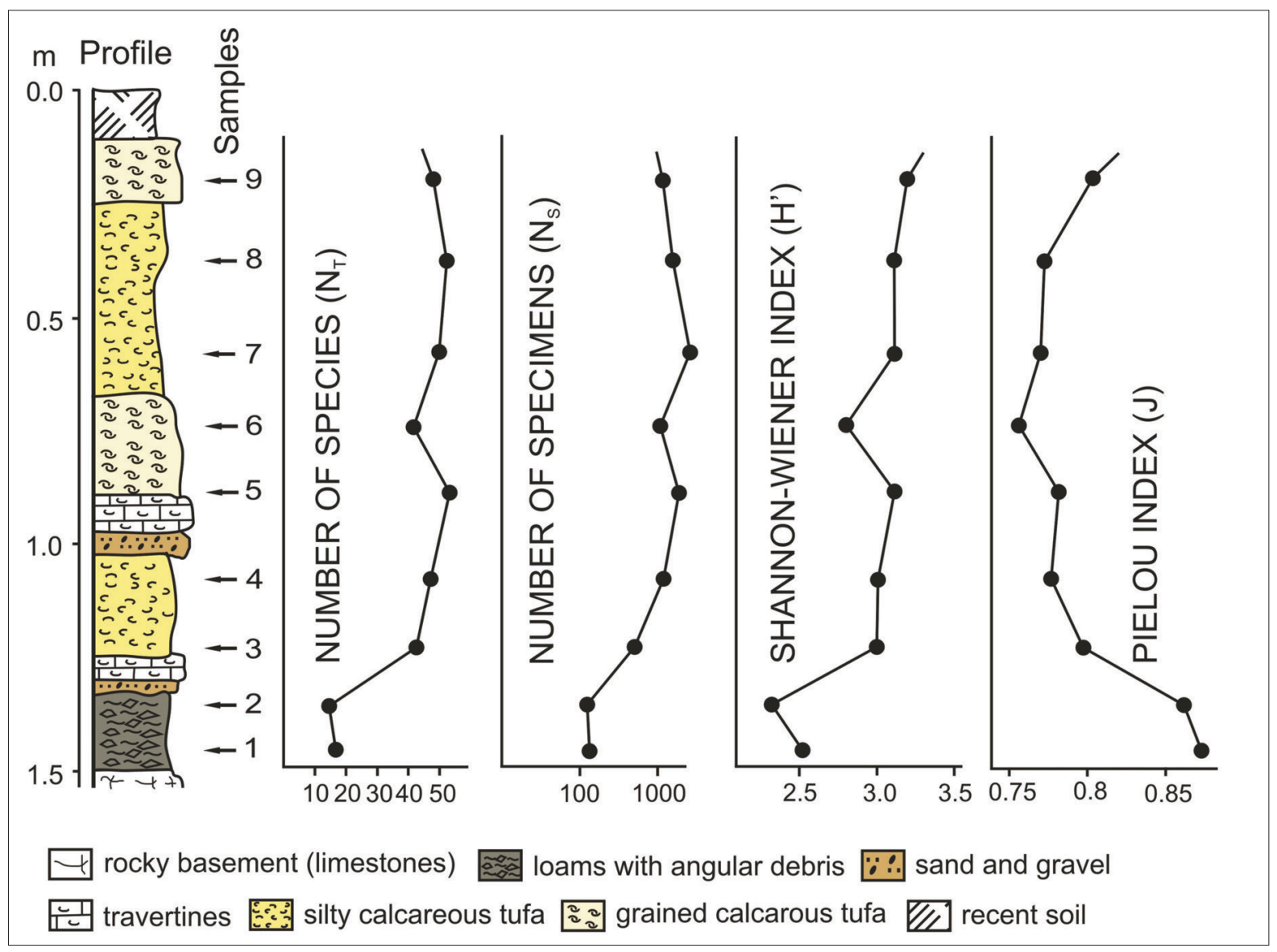

Fig. 2. Profile, numbers of species and specimens and diversity indices of malacofauna from calcareous tufa in the Ociemny Stream valley

\section{MATERIAL AND METHOD}

In connection to lithological formation of the profile, nine samples were collected, each weighing approx. $3 \mathrm{~kg}$ and contains intervals about $15 \mathrm{~cm}$ thick, in order to perform malacological analysis. The samples were subjected to standard laboratory procedure involving flushing on $0.5 \mathrm{~mm}$ sieve, drying, and the removal of shell material. Then, the identification of shells and their fragments to species and finding the numbers of particular taxa were performed. The species were classified to relevant ecological groups in accordance with the schemes worked out by Ložek (1964) and S.W. Alexandrowicz \& W.P. Alexandrowicz (2011). Five ecological groups were distinguished in the studied material: $\mathrm{F}$ - shade-loving species, $\mathrm{O}$ - species of open environments, $\mathrm{M}$ - mesophilous species, $\mathrm{H}$ - hygrophilous species, and $\mathrm{W}$ - water species. The percentage of shares of ecological groups in samples was the basis for the construction of the malacological spectrum among individuals. In order to characterise species diversity in particular samples, the diversity index (Shannon-Wiener $\mathrm{H}^{\prime}$ ), and the homogeneity index (evenness) (Pielou - J) (Shannon \& Weaver 1949, Pielou 1975) were calculated in each of them. The overall zoogeographical analysis was based on the system of grouping species into zoogeographical groups described by S.W. Alexandrowicz \& W.P. Alexandrowicz (2011). The great diversity of species within the profile enabled the separation of three fauna assemblages. The basis for separation was the analysis of the dendrogram of similarities calculated using Morisita's formula (1959). The calculations of diversity and homogeneity indices, indispensable to the construction of the dendrogram, were performed with the use of PAST software package (Hammer et al. 2001). Drawing stratigraphic conclusions was based on the comparison of the mollusc assemblages found in the studied tufas with the malacoenoses described in other 
profiles in the Pieniny Mts. and the neighbouring areas (Flysh Carpathians and Podhale Basin).

\section{RESULTS}

Very numerous molluscan shells occurred in nine samples collected in loams and calcareous tufas exposed in the Ociemny Stream valley. In total, the presence of 69 species of land snails, and two species of aquatic snails, represented by more than 11,000 specimens was found. The numbers of taxa occurring in particular samples varied from 16 to 54 , and the number of specimens varied from 176 to 3059 (Fig. 2, Tab. 1).

The malacofauna identified in the profile of calcareous tufas in the Ociemny Stream valley is very rich. The fauna found in in the bottom part of the sequence (samples Oc-1 and Oc-2) contains a low number of species (19 and 16 respectively) represented by relatively few specimens (179 and 176 respectively) (Tab. 1). The low diversity in this malacoenose is further emphasised by low values of diversity index ( $\left.\mathrm{H}^{\prime}\right)$ (2.53 and 2.34) and by high values of the homogeneity index (J) (0.875 and 0.863 ) (Fig. 2). The diversity of the fauna increases in the higher potion of the profile (samples Oc-3 - Oc-9). It is marked by a rapid increase in the number of species (up to a maximum of 54 in samples Oc- 5 and Oc-8) and of specimens (up to a maximum of 3059 - sample Oc-7), with markedly higher values of the $\mathrm{H}^{\prime}$ index falling into 2.81-3.33 range and by lower values of $\mathrm{J}$ index (0.756-0.796 range) (Fig. 2).

Table 1

List of species recognized in calcareous tufa in the Ociemny Stream valley

\begin{tabular}{|c|c|c|c|c|c|c|c|c|c|c|}
\hline \multirow{2}{*}{$\mathrm{E}$} & \multirow{2}{*}{ Taxon } & \multicolumn{9}{|c|}{ Samples } \\
\hline & & Oc-1 & Oc-2 & Oc-3 & Oc-4 & Oc-5 & Oc-6 & Oc-7 & Oc-8 & Oc-9 \\
\hline F & Acicula parcelineata (Cless., 1911) & & & 1 & 2 & 9 & 8 & 16 & & \\
\hline $\mathrm{F}$ & Platyla polita (Hartm., 1840) & & 1 & 43 & 42 & 74 & 31 & 92 & 40 & 10 \\
\hline $\mathrm{F}$ & Vertigo pusilla Müller, 1774 & & & 2 & 4 & 4 & & & 2 & 2 \\
\hline $\mathrm{F}$ & Sphyradium doliolum (Brug., 1792) & & & 15 & 24 & & & & & \\
\hline $\mathrm{F}$ & Argna bielzi (Rossm., 1859) & & & & & & 1 & & 1 & 3 \\
\hline $\mathrm{F}$ & Acanthinula aculeata (Müller, 1774) & & & 5 & 19 & 9 & 3 & 10 & 2 & 2 \\
\hline $\mathrm{F}$ & Ena montata (Drap., 1801) & & & 4 & 2 & 20 & 19 & 36 & 11 & 41 \\
\hline $\mathrm{F}$ & Merdigera obscura (Müller, 1774) & & & & & & & & 1 & \\
\hline $\mathrm{F}$ & Discus perspectivus (Mühl., 1816) & & & 82 & 125 & 89 & 41 & 127 & 36 & 26 \\
\hline $\mathrm{F}$ & Discus rotundatus (Müller, 1774) & & & 43 & 34 & 33 & 9 & 67 & 5 & 30 \\
\hline $\mathrm{F}$ & Discus ruderatus (Hartm., 1821) & 32 & 29 & 25 & 6 & 12 & 8 & 33 & 2 & 2 \\
\hline $\mathrm{F}$ & Eucobresia nivalis (Dum. \& Mort., 1854) & 1 & 1 & 22 & 18 & 24 & 5 & 19 & 3 & 3 \\
\hline $\mathrm{F}$ & Semilimax semilimax (Fér., 1802) & & & & & & & 3 & & \\
\hline F & Semilimax kotulae (West., 1883) & 29 & 19 & 6 & 1 & & & & & \\
\hline $\mathrm{F}$ & Vitrea diaphana (Stud., 1820) & 2 & 1 & 30 & 29 & 103 & 60 & 164 & 93 & 69 \\
\hline $\mathrm{F}$ & Vitrea transsylvanica (Cless., 1877) & & & 10 & 25 & 33 & 17 & 24 & 10 & 14 \\
\hline $\mathrm{F}$ & Vitrea subrimata (Reinh., 1871) & 3 & & & & & & 18 & 2 & \\
\hline $\mathrm{F}$ & Vitrea crystallina (Müller, 1774) & 2 & 1 & 60 & 71 & 47 & 21 & 46 & 20 & 20 \\
\hline $\mathrm{F}$ & Aegopinella minor (Stab., 1864) & & & 10 & 30 & 36 & 12 & 32 & 31 & 17 \\
\hline $\mathrm{F}$ & Aegopinella nitens (Mich., 1831) & & & 30 & 24 & 28 & 8 & 27 & & \\
\hline $\mathrm{F}$ & Aegopinella pura (Ald., 1830) & 2 & & 88 & 72 & 129 & 49 & 73 & 32 & 27 \\
\hline $\mathrm{F}$ & Mediterranea depressa (Sterki, 1880) & & & 2 & 3 & 8 & 2 & 5 & 4 & 4 \\
\hline $\mathrm{F}$ & Daudebardia rufa (Drap., 1805) & & & & & & & & 1 & \\
\hline $\mathrm{F}$ & Cochlodina laminata (Mont., 1803) & & & 1 & 1 & 17 & & 21 & 6 & \\
\hline $\mathrm{F}$ & Cochlodina orthostoma (Menke, 1828) & & & & & 5 & 2 & 7 & 3 & 2 \\
\hline $\mathrm{F}$ & Ruthenica filograna (Rossm., 1836) & & & 53 & 66 & 73 & 15 & 63 & 17 & 15 \\
\hline $\mathrm{F}$ & Macrogastra plicatula (Drap., 1801) & 1 & & 2 & 17 & 10 & & 7 & 12 & \\
\hline $\mathrm{F}$ & Macrogastra borealis (Boett., 1878) & & & & 12 & 8 & & 12 & & \\
\hline $\mathrm{F}$ & Macrogastra tumida (Rossm., 1836) & & & 5 & 3 & 13 & & & 8 & 4 \\
\hline $\mathrm{F}$ & Clausilia cruciata (Stured, 1820) & & & 24 & 34 & 14 & & & & \\
\hline
\end{tabular}


Table 1 cont.

\begin{tabular}{|c|c|c|c|c|c|c|c|c|c|c|}
\hline F & Vestia gulo (E.A. Bielz, 1859) & & & & 15 & 5 & & & & \\
\hline $\mathrm{F}$ & Vestia turgida (Rossm., 1836) & & & 2 & 8 & 19 & 2 & 13 & 7 & 7 \\
\hline $\mathrm{F}$ & Balea stabilis (L. Pfe., 1847) & & & & & 8 & & & 3 & 5 \\
\hline $\mathrm{F}$ & Balea biplicata (Mont., 1803) & & & & & 12 & & 21 & 7 & 3 \\
\hline $\mathrm{F}$ & Fruticicola fruticum (Müller, 1774) & & & 8 & 3 & 20 & 2 & 15 & 17 & 52 \\
\hline $\mathrm{F}$ & Perforatella bidentata (Gmel., 1791) & 4 & & 1 & 13 & 72 & 30 & 90 & 39 & 89 \\
\hline $\mathrm{F}$ & Monachoides incarnatus (Müller, 1774) & & & 3 & 2 & 25 & 12 & 72 & 23 & 42 \\
\hline $\mathrm{F}$ & Monachoides vicinus (Rossm., 1842) & & & 3 & 7 & 184 & 59 & 217 & 74 & 109 \\
\hline $\mathrm{F}$ & Urticicola umbrosus (C. Pfe., 1828) & & & & & & & 14 & 15 & \\
\hline F & Trochulus unidentatus (Drap., 1805) & & & 4 & 3 & 58 & 35 & 56 & 31 & 34 \\
\hline $\mathrm{F}$ & Faustina faustina (Rossmässler, 1835) & & & 4 & 21 & 36 & 32 & 139 & 40 & 18 \\
\hline $\mathrm{F}$ & $\begin{array}{l}\text { Isognomostoma isognomostomos } \\
\text { (Schröt., 1784) }\end{array}$ & & & 59 & 43 & 272 & 71 & 264 & 98 & 132 \\
\hline $\mathrm{F}$ & Arianta arbustorum (L., 1758) & 2 & 8 & & & 31 & 3 & 19 & 23 & 40 \\
\hline $\mathrm{F}$ & Helix pomatia (L., 1758) & & & & & & & 15 & & \\
\hline $\mathrm{O}$ & Truncatellina cylindrica (Fér., 1807) & & & & & 2 & 1 & 3 & 2 & 4 \\
\hline $\mathrm{O}$ & Pupilla muscorum (L., 1758) & & & & & & & 5 & 2 & 16 \\
\hline $\mathrm{O}$ & Vallonia costata (Müller, 1774) & & & 37 & 91 & 17 & 2 & 8 & 5 & 21 \\
\hline $\mathrm{O}$ & Vallonia pulchella (Müller, 1774) & & & & & 16 & 4 & 6 & 11 & 20 \\
\hline $\mathrm{M}$ & Carychium tridentatum (Risso, 1826) & 3 & 2 & 104 & 104 & 130 & 60 & 115 & 33 & 17 \\
\hline $\mathrm{M}$ & Cochlicopa lubrica (Müller, 1774) & & & 2 & 14 & 21 & 6 & 26 & 8 & 12 \\
\hline$M$ & Succinella oblonga (Drap., 1801) & 22 & 15 & 38 & 58 & 67 & 12 & 31 & 15 & 7 \\
\hline M & Columella edentula (Drap., 1805) & & & & 1 & 2 & & 2 & & \\
\hline $\mathrm{M}$ & Columella columella (Mart., 1830) & 14 & 21 & 4 & 1 & & & & & \\
\hline $\mathrm{M}$ & Vertigo alpestris Ald., 1837 & & & & & & & & 1 & \\
\hline$M$ & Vertigo substriata (Jeff., 1833) & 41 & 39 & 9 & 5 & 6 & 6 & 10 & 6 & \\
\hline $\mathrm{M}$ & Vertigo angustior Jeff., 1830 & & & 2 & & & & & & \\
\hline M & Punctum pygmaeum (Drap., 1801) & & & 7 & 6 & 3 & & & & 1 \\
\hline M & Vitrina pellucida (Müller, 1774) & & & & & 1 & 3 & 7 & 3 & 6 \\
\hline $\mathrm{M}$ & Vitrea contracta (West., 1871) & & & & & 1 & & & 6 & 9 \\
\hline $\mathrm{M}$ & Perpolita hammonis (Ström, 1765) & & & 1 & 2 & 1 & & & 1 & 1 \\
\hline $\mathrm{M}$ & Limacidae & 1 & 4 & 4 & 3 & 14 & 2 & 24 & 7 & 2 \\
\hline $\mathrm{M}$ & Euconulus fulvus (Müller, 1774) & 1 & 4 & 5 & 3 & 1 & 5 & 4 & & \\
\hline $\mathrm{M}$ & Clausilia dubia Drap., 1805 & & 6 & & 3 & 7 & & & & 12 \\
\hline M & Trochulus villosus (Rossmässler, 1838) & & & & 4 & 31 & 26 & 39 & 20 & 21 \\
\hline $\mathrm{H}$ & Carychium minimum Müller, 1774 & & & 14 & 6 & 36 & 20 & 50 & 10 & 1 \\
\hline $\mathrm{H}$ & Succinea putris (L., 1758) & & & & & & & & 2 & 12 \\
\hline $\mathrm{H}$ & Vertigo genesii (Gredl., 1856) & 10 & 13 & 1 & & & & & & \\
\hline $\mathrm{H}$ & Vertigo geyeri Lindh.,1925 & 12 & 12 & 1 & & & & & & \\
\hline $\mathrm{H}$ & Zonitoides nitidus (Müller, 1774) & & & & & & & & & 1 \\
\hline $\mathrm{W}$ & Bythinella austiaca (Frau., 1857) & & & & & 589 & 372 & 870 & 329 & 149 \\
\hline $\mathrm{W}$ & Galba truncatula (Müller, 1774) & 2 & & 3 & 5 & 6 & 8 & 22 & 7 & \\
\hline \multicolumn{2}{|r|}{ Total species (69) } & 19 & 16 & 45 & 48 & 54 & 41 & 50 & 54 & 48 \\
\hline \multicolumn{2}{|c|}{ Total specimens (11 225) } & 179 & 176 & 877 & 1085 & 2491 & 1084 & 3059 & 1188 & 1136 \\
\hline \multicolumn{2}{|c|}{ Indeterminate shells fragments (846) } & 34 & 37 & 97 & 83 & 124 & 80 & 211 & 102 & 78 \\
\hline
\end{tabular}

E - ecological groups of molluscs (after: Ložek 1964, S.W. Alexandrowicz \& W.P. Alexandrowicz 2011), F - shade-loving species, $\mathrm{O}$ - open-country species, $\mathrm{M}$ - mesophilous species, $\mathrm{H}$ - hygrophilous species, $\mathrm{W}$ - water species

The malacofauna identified in calcareous tufas of the Ociemny stream shows great ecological diversity. Species occurring there are classified into five ecological groups. The most important component of the fauna are shade-loving snails (ecological group F), represented by 44 taxa and more than 7,000 specimens. In the lower part of the sequence (samples Oc-1 and Oc-2), there is a characteristic presence of Discus ruderatus and Semilimax kotulae. These are forms preferring 
cold climate, and principally inhabiting coniferous forests on a moist substrate (Fig. 3, Tab. 1). In the higher part of the profile (samples Oc-3 and Oc-4), there is an evident increase in the diversity of the shade-loving element. Semilimax kotulae disappears, while Discus ruderatus is replaced by Discus perspectivus. The latter is a taxon that requires moist, oceanic climate, and forests with a high proportion of deciduous trees (Dehm 1987, Alexandrowicz et al. 2014, 2016). It is accompanied by many other species with similar high ecological requirements, i.e. Ruthenica filograna, Clausilia cruciata, and Aegopinella pura. In the section of profile discussed here, the proportion of shade-loving forms is the greatest and exceeds $50 \%$ of the assemblage (Fig. 3, Tab. 1). In the upper part of the sequence (samples Oc-5 - Oc-9), the prevalence of shade-loving snails is still evident, and their proportion in the assemblage reaches up to $50 \%$. The frequent occurrence of forms preferring shadowy habitats on moist substrate is characteristic here, e.g., Perforatella bidentata, Mo- nachoides vicinus, and Vitrea crystallina (Fig. 3, Tab. 1).

The snails of open habitats (ecological group O) are the faunal component of secondary importance. Here, a mere four species were found, numbering less than 300 specimens. These taxa occur in the middle and upper part of the sequence (samples Oc-3 and Oc-4, as well as Oc-8 and Oc-9) (Fig. 3, Tab. 1).

Mesophilous species (ecological group M) are the most important component of the floor part of the profile, where they constitute up to $40 \%$ of the assemblage. Here, the particularly characteristic is the occurrence of cold-tolerant species Columella columella accompanied by similarly numerous boreal form Vertigo substriata. Both these taxa are typical of relatively open, moist habitats and cool climate. They disappear in the middle and upper parts of the sequence, being replaced by much less numerous forms of great ecological tolerance, i.e. Carychium tridentatum and Cochlicopa lubrica (Fig. 3, Tab. 1).

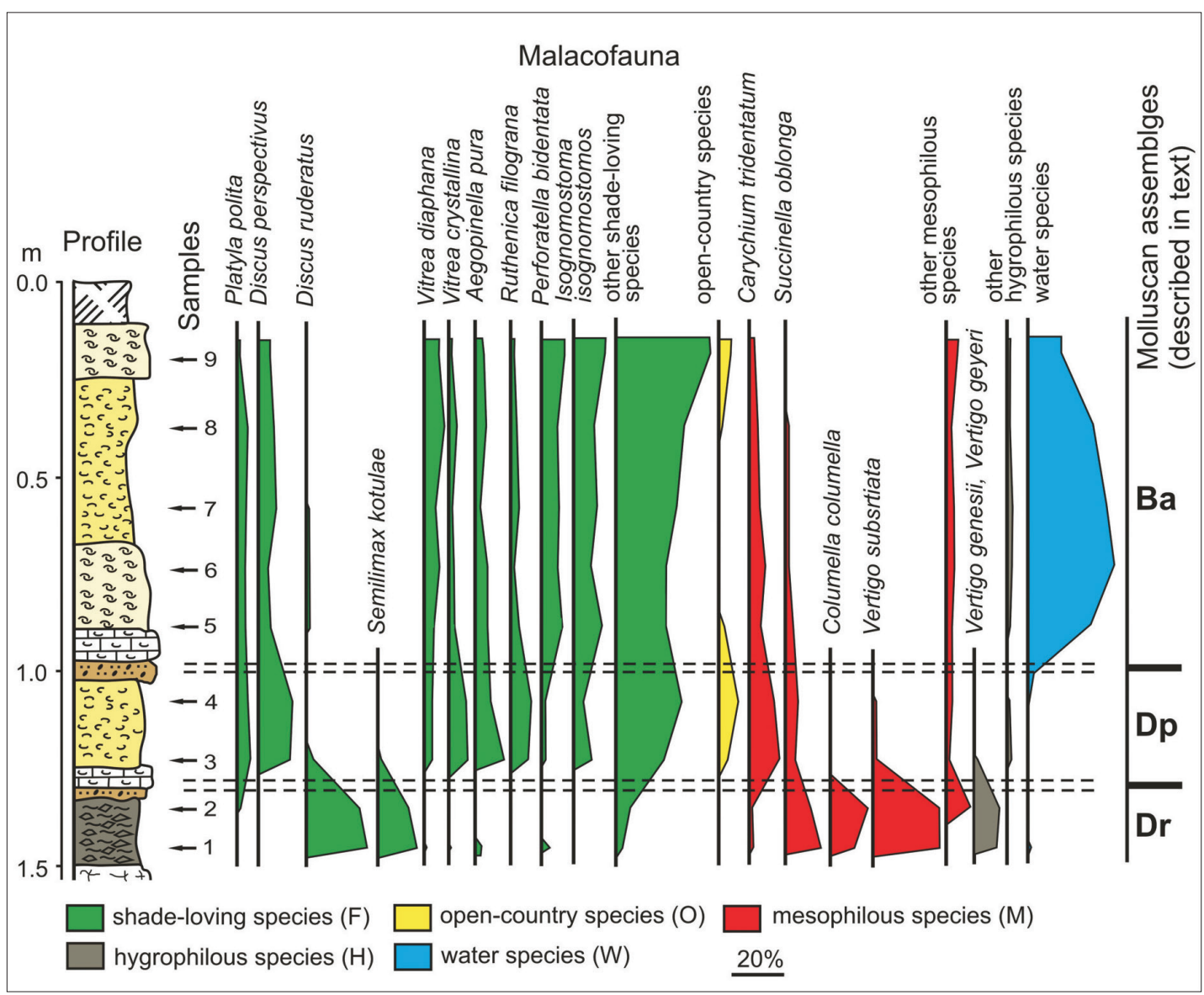

Fig. 3. Malacological percentage diagram of fauna from calcareous tufa in the Ociemny Stream valley 
Hygrophilous snails (ecological group $\mathrm{H}$ ) are rare throughout the sequence. Nevertheless, the presence of cold-tolerant taxa Vertigo genesii and Vertigo geyeri in the lowest part is noteworthy (Fig. 3, Tab. 1).

Water snails (ecological group W) are represented by only two species. The first (Galba truncatula) occurs rarely, whereas the other (Bythinella austriaca) is the most often occurring snail in the studied site. It occurs solely in the upper interval of the sequence (samples Oc-5 - Oc-9) reaching very high numbers. This is a stenotopic taxon characteristic of springs with constant temperature (Fig. 3, Tab. 1).

The zoogeographic structure of the fauna identified in the calcareous tufas of the Ociemny Spring shows significant diversity. Widely distributed species appear across the whole profile; however, they play more important role in the lower interval (Holarctic and Euro-Siberian forms) and in the middle interval (Palearctic and European forms). In the upper section, the Central-European species, particularly mountain species, are the most important. The species of limited geographic distribution are relatively sparse and occur chiefly in the middle and upper portions of the profile. The presence of thermophilous Balkan and Mediterranean forms such as Sphyradium doliolum are also noteworthy. In the group under discussion, the boreal-alpine snails are an exception, which constitutes the most important component in the assemblage identified in the bottom interval of the sequence where they are more than $40 \%$ of the assemblage. This group principally includes the cold-tolerant taxa: Columella columella, Vertigo genesii, Vertigo geyeri, as well as boreal snail Vertigo substriata (Fig. 4).

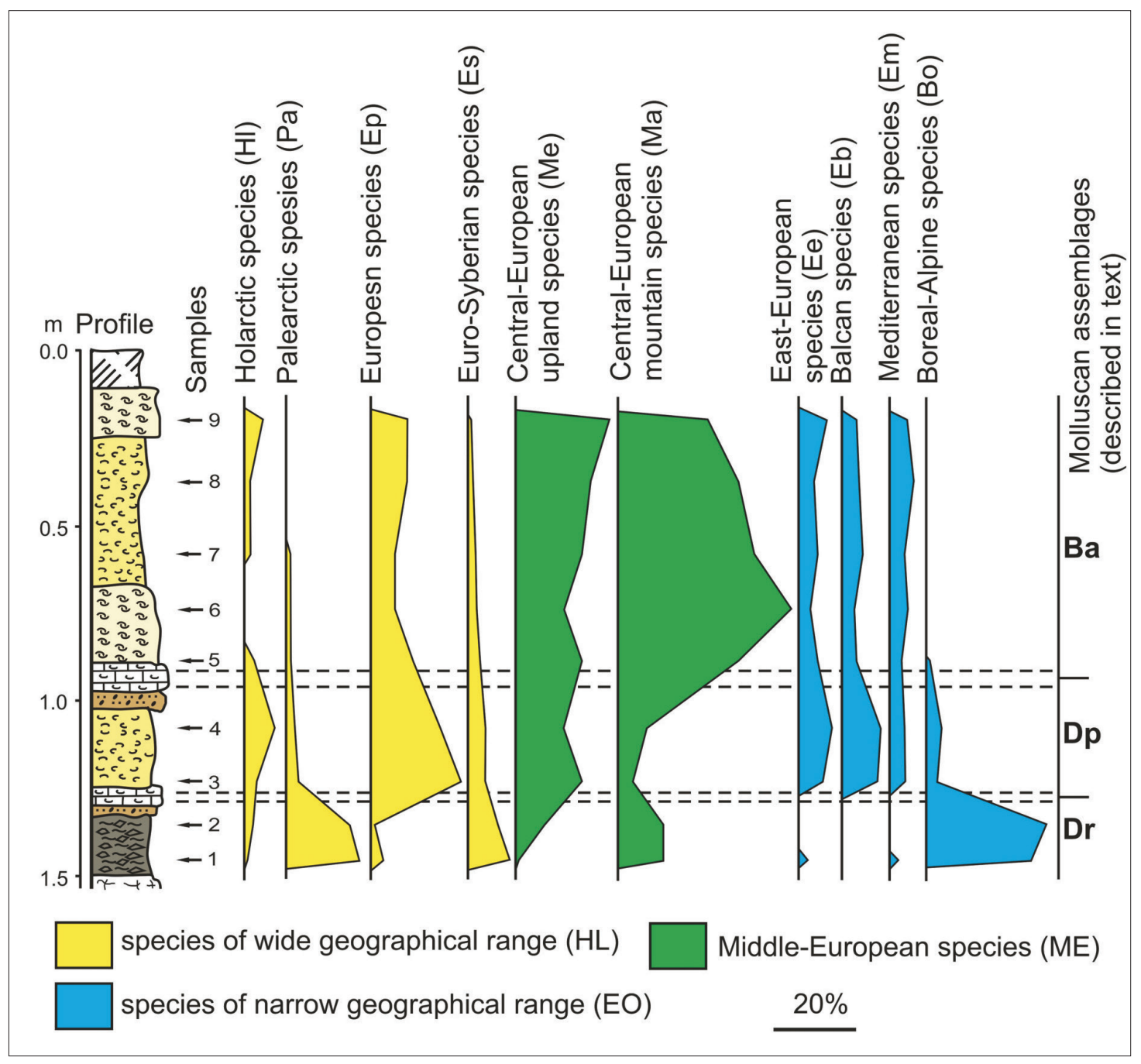

Fig. 4. Zoogeographical structure of molluscan fauna from calcareous tufa in the Ociemny Stream valley 


\section{DISCUSSION}

\section{Molluscan assemblages}

In the profile of calcareous tufas in the Ociemny Stream, the differences in species composition and the structure of malacoenoses are very marked. These are the basis for separating faunal assemblages. The analysis of dendrograms of similarities enables the distinguishing of three such assemblages (Fig. 5).

The assemblage with Discus ruderatus (Dr) appears in the floor interval of the sequence (samples Oc-1 and Oc-2) (Figs. 3-5). It is a relatively poor and little diversified assemblage showing low values of the diversity index $\left(\mathrm{H}^{\prime}\right)$ and high values of the homogeneity index (J) (Fig. 2). Two groups of species are the most important in this assemblage. The first are shade-loving forms represented chiefly by Discus ruderatus and Semilimax kotulae. The other group includes mesophilous snails, including Columella columella and Vertigo substriata, which are most numerous. Another component of the described fauna constitutes also cold-tolerant and hygrophilous forms, i.e. Vertigo genesii and Vertigo geyeri. The zoogeographic composition shows the predomination of species with a wide geographic distribution, particularly of the Palearctic and European, as well as Boreal-Arctic distributions (Figs. 3, 4). The presented assemblage shows the features of "Ruderatus-fauna" (Dehm 1967). It indicates the predomination of shaded habitats with great humidity of the substrate. The predominant vegetation formations were forests of taiga type. The above-described malacoenosis is characteristic of cold climate with fairly well marked continental features. The presence of cold-tolerant taxa (i.e. Columella columella, Vertigo genesii, Vertigo geyeri, and Semilimax kotulae) is of particular importance to the fauna found there. These species were common components of assemblages associated with Late Glacial period and - in line with warming climate during the Holocene - their ranges have shrank gradually, so that, at present, they are known only from single, isolated locations (Pokryszko 1991, Limondin-Lozouet 1992, Schenkova et al. 2012, Schenkova \& Horsák 2013). At present, none of these forms occurs within the Pieniny Mts. However, the current occurrence of Vertigo geyeri and Semilimax kotulae were found within the Podhale Basin (W.P. Alexandrowicz 1997, 2004, 2010, 2013a, Schenkova \& Horsák 2013).

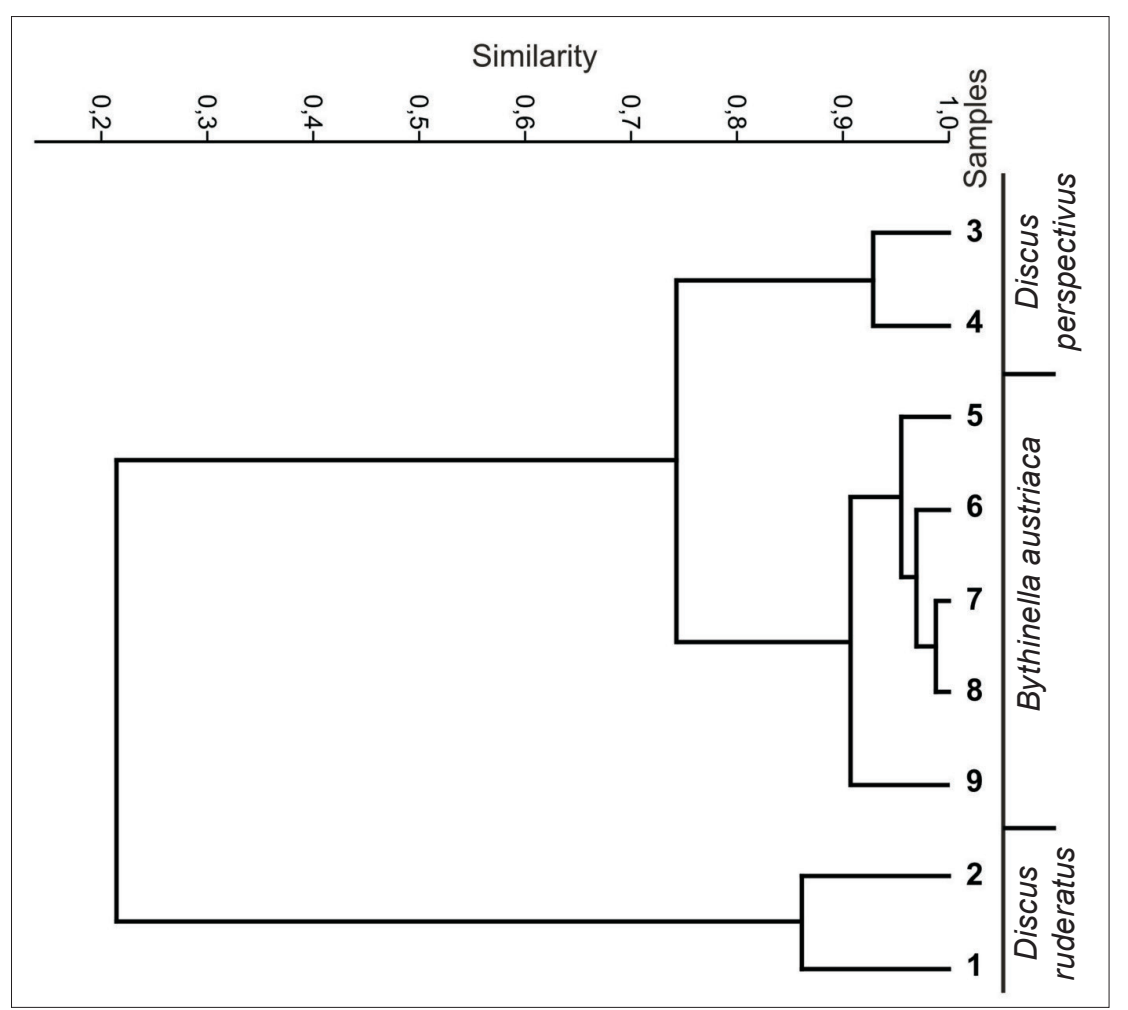

Fig. 5. Cluster analysis of malacofauna from calcareous tufa in the Ociemny Stream valley 
All four species in question are often found in the sediments of Early Holocene described in the Podhale region (W.P. Alexandrowicz 1997, 2001, 2003, 2013b, 2015, W.P. Alexandrowicz \& Rybska, 2013, W.P. Alexandrowicz et al. 2014), Pieniny Mts. (S.W. Alexandrowicz 1996, W.P. Alexandrowicz et al. 2016) and the Beskidy Mts. (S.W. Alexandrowicz \& Z. Alexandrowicz 1999, W.P. Alexandrowicz 2004).

The assemblage with Discus ruderatus is considered as indicative for the Early Holocene, and has been described in this stratigraphic position in a number of locations in Central and Western Europe (Preece \& Day 1994, Gedda 2001, 2006, Meyrick 2002, Žak et al. 2002, Limondin-Lozouet \& Preece 2004, Limondin-Lozouet 2011, Juřičková et al. 2014, Horáčková et al. 2015). The fauna occurring in the floor of the profile of calcareous tufas in the Ociemny Stream valley can only be associated with that period (Fig. 6). Such an interpretation is confirmed by the determination of the age of sediment containing very similar fauna assemblages conducted in many locations within the Beskidy Mts. and Podhale regions (Tab. 2).

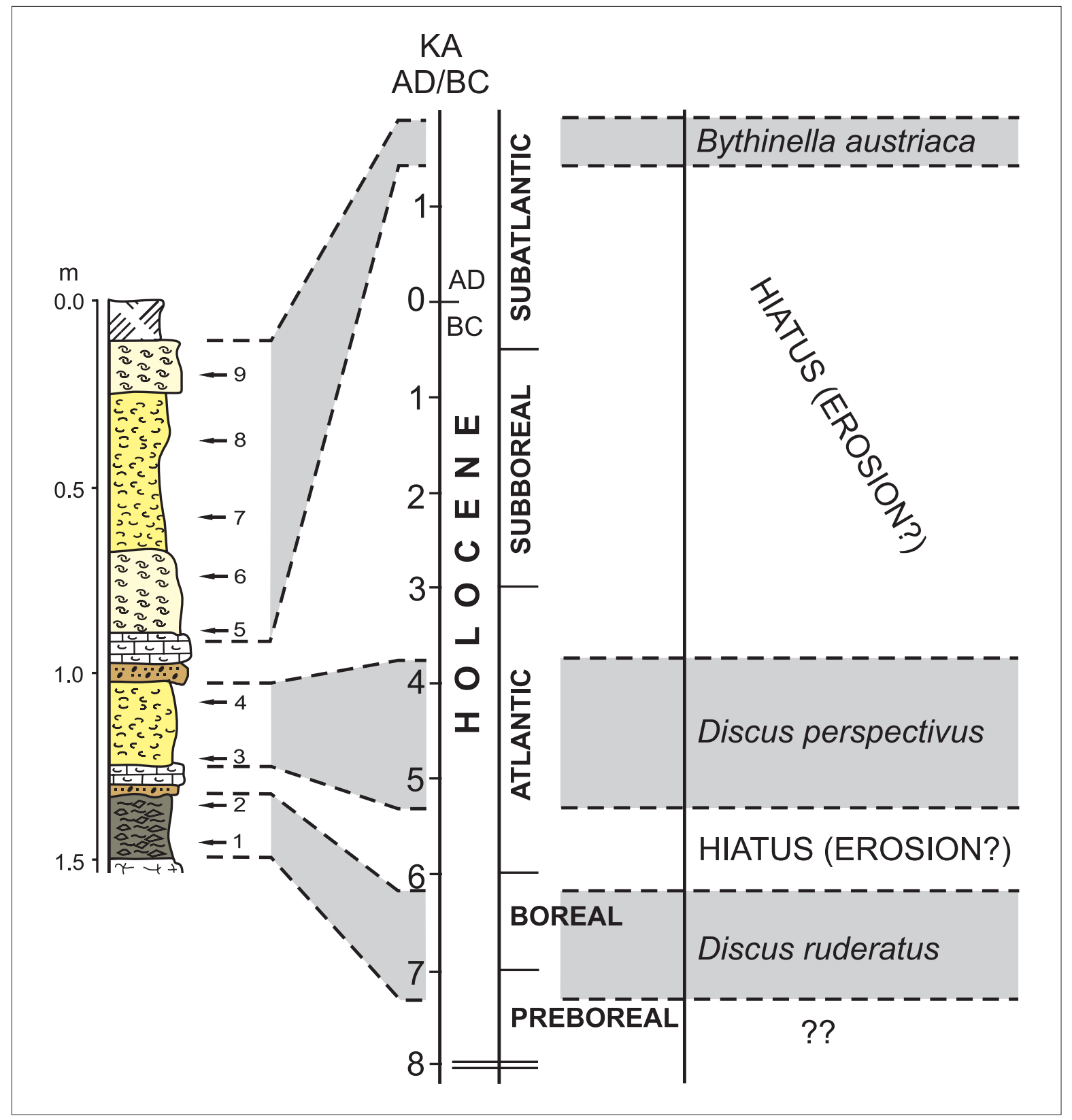

Fig. 6. Stratigraphy of calcareous tufa in the Ociemny Stream valley 
Table 2

Stratigraphical value of molluscan assemblages described from Holocene mollusc-bearing deposits from Pieniny Mts (PM) and Podhale Basin (PB)

\begin{tabular}{|c|c|c|c|}
\hline \multirow{2}{*}{ Locality } & \multicolumn{2}{|c|}{ Stratigraphical data } & \multirow{2}{*}{ References } \\
\hline & C14 (BP) & Cal C14 (BC/AD) & \\
\hline \multicolumn{4}{|c|}{ Assemblage with Bythinella austriaca } \\
\hline Sobczański Gorge (PM) & $\begin{array}{c}620 \pm 80 \\
60 \pm 30\end{array}$ & $\begin{array}{l}1253-1431 \mathrm{AD} \\
1697-1916 \mathrm{AD}\end{array}$ & W.P. Alexandrowicz 2004, 2010, 2014 \\
\hline Zawiasy (PM) & $320 \pm 40$ & $1496-1646 \mathrm{AD}$ & W.P. Alexandrowicz 2004, 2010, 2014 \\
\hline Gorczyński Gorge (PM) & $140 \pm 70$ & $1650-1947 \mathrm{AD}$ & W.P. Alexandrowicz 2004, 2010, 2014 \\
\hline Tylka PM) & $535 \pm 30$ & $1330-1430 \mathrm{AD}$ & $\begin{array}{l}\text { S.W. Alexandrowicz } 1997 \\
\text { W.P. Alexandrowicz 2004, 2013c }\end{array}$ \\
\hline Płaśnie (PM) & $680 \pm 80$ & $1206-1423 \mathrm{AD}$ & $\begin{array}{l}\text { S.W. Alexandrowicz } 1997 \\
\text { W.P. Alexandrowicz 2004, 2013c }\end{array}$ \\
\hline Jaworki (PM) & $450 \pm 50$ & $1398-1523 \mathrm{AD}$ & W.P. Alexandrowicz 2004, 2010 \\
\hline Kozłecki Stream (PM) & $140 \pm 50$ & $1670-1950 \mathrm{AD}$ & S.W. Alexandrowicz 1993, 1997 \\
\hline Ścigocki Stream (PM) & $\begin{array}{l}640 \pm 50 \\
250 \pm 40\end{array}$ & $\begin{array}{l}1275-1404 \mathrm{AD} \\
1515-1805 \mathrm{AD}\end{array}$ & S.W. Alexandrowicz 1993, 1997 \\
\hline Homole Gorge (PM) & $480 \pm 40$ & $1298-1527 \mathrm{AD}$ & S.W. Alexandrowicz 1997 \\
\hline Długi Gronik (PM) & $480 \pm 50$ & $1388-1499 \mathrm{AD}$ & W.P. Alexandrowicz 2004, 2010 \\
\hline Grajcarek (PM) & $450 \pm 35$ & $1410-1491 \mathrm{AD}$ & W.P. Alexandrowicz 2004, 2010 \\
\hline Falsztyn (PB) & $230 \pm 50$ & $1513-1815 \mathrm{AD}$ & W.P. Alexandrowicz 2010 \\
\hline Łapsze Wyżne (PB) & $180 \pm 50$ & $1647-1891 \mathrm{AD}$ & W.P. Alexandrowicz 1997, 2010 \\
\hline Stawiska (PB) & $390 \pm 35$ & $1439-1632 \mathrm{AD}$ & W.P. Alexandrowicz 1997, 2010 \\
\hline Niedzica (PB) & $620 \pm 60$ & $1278-1417 \mathrm{AD}$ & $\begin{array}{l}\text { W.P. Alexandrowicz } 1997 \\
\text { W.P. Alexandrowicz \& Rybska } 2013\end{array}$ \\
\hline \multicolumn{4}{|c|}{ Assemblage with Discus perspectivus } \\
\hline Łapsze Niżne (PB) & $7410 \pm 130$ & $6480-6010 \mathrm{BC}$ & W.P. Alexandrowicz 2015 \\
\hline Falsztyński Potok (PB) & $5610 \pm 130$ & $4784-4173 \mathrm{BC}$ & W.P. Alexandrowicz 1997 \\
\hline Zaskale (PM) & $6500 \pm 270$ & $5942-4847 \mathrm{BC}$ & W.P. Alexandrowicz 2004 \\
\hline Harcygrunt (PM) & $7750 \pm 130$ & $7032-6403 \mathrm{BC}$ & S.W. Alexandrowicz 1997 \\
\hline Niedzica (PB) & $8010 \pm 110$ & $7193-6614$ BC & $\begin{array}{l}\text { W.P. Alexandrowicz } 1997 \\
\text { W.P. Alexandrowicz \& Rybska } 2013\end{array}$ \\
\hline \multicolumn{4}{|c|}{ Assemblage with Discus ruderatus } \\
\hline Majerz (PB) & $9040 \pm 90$ & $8483-7955$ BC & W.P. Alexandrowicz 2015 \\
\hline Groń (PB) & $9060 \pm 90$ & $8491-7966 \mathrm{BC}$ & W.P. Alexandrowicz 2013b \\
\hline Niedzica (PB) & $8660 \pm 130$ & 8019-7517 BC & $\begin{array}{l}\text { W.P. Alexandrowicz } 1997 \\
\text { W.P. Alexandrowicz \& Rybska } 2013\end{array}$ \\
\hline Łapsze Niżne (PB) & $8800 \pm 100$ & $8236-7611 \mathrm{BC}$ & W.P. Alexandrowicz 1997 \\
\hline Łapsze (PB) & $8150 \pm 110$ & $7482-6780 \mathrm{BC}$ & W.P. Alexandrowicz 1997 \\
\hline
\end{tabular}

The assemblage with Discus perspectivus (Dp) appears in the middle section of the sequence (samples Oc-3 and Oc-4) (Figs. 3-5). It is a very rich and highly diversified fauna, showing high values of the diversity index $\left(\mathrm{H}^{\prime}\right)$ and low values of the homogeneity index (J) (Fig. 2). The assemblage in question is characterised by the predominance of shade-loving species whose proportion exceeds $50 \%$. The forms typical of coniferous forests (i.e. Discus ruderatus and Semilimax kotulae), occurring in great numbers in the previous assemblage, disappear and are replaced by species requiring warmer and somewhat more humid climate, i.e.
Discus perspectivus, Ruthenica filograna, and Aegopinella pura and several other species. The coldtolerant, mesophilous and hygrophilous taxa, such as Columella columella, Vertigo genesii, and Vertigo geyeri, also disappear (Fig. 3). The zoogeographic structure of the fauna is also greatly changed. The European and Central-European forms become prevalent. The species with limited distribution ranges, including the thermophilous Balkan and Mediterranean (Sphyradium doliolum) taxa are also becoming important (Fig. 4). The assemblage mentioned above have both a composition and structure similar to "Perspectivus-fauna" 
(Dehm 1987). It is characteristic of forest communities with major proportions of deciduous trees, showing great diversity of species. This fauna is characteristic of a warm and humid climate with clearly displayed oceanic features.

The assemblage with Discus perspectivus is considered to be an indicative assemblage of the Atlantic Phase, and it has been noted in this stratigraphic position in many locations in Europe (e.g. Dehm 1987, Füköh 1993, 1995, W.P. Alexandrowicz 1997, 2003, 2004, 2015, Meyrick 2002, Žak et al. 2002, W.P. Alexandrowicz \& Rybska, 2013, W.P. Alexandrowicz et al. 2014, 2016, Juřričková et al. 2014, Horáčková et al. 2015). The rich and diversified malacoenosis identified in the mid-section of the calcareous tufa profile in the Ociemny Stream valley can be linked with this phase (Fig. 6). Similar fauna assemblages were found in several neighbouring locations where they were dated by radiocarbon method (Tab. 2).

The assemblage with Bythinella austriaca $(\mathrm{Ba})$ occurs in the upper part of the sequence (samples Oc-5 and Oc-9) (Figs 3-5). It is a rich fauna, showing high values of the diversity index $\left(\mathrm{H}^{\prime}\right)$ and low values of the homogeneity index (J) (Fig. 2). Two groups of species predominate in this fauna. The first are shade-loving snails, represented by numerous species. High frequencies of forms preferring humid forest communities are also found, i.e. Perforatella bidentata, Monachoides vicinus, and Vitrea crystallina. In parallel to this, numbers of thermophilous species, common in the assemblage with Discus perspectivus described above were also found. Another important component of the fauna under discussion is aquatic snails, particularly Bythinella austriaca. This stenotopic species inhabiting spring zones achieves very high numbers of specimens and thus can constitute up to $30 \%$ of the assemblage. The proportion of remaining ecological groups is minor (Fig. 3). In the zoogeographical structure, this is a notable and very high occurrence of Central-European species, including both mountain and upland species. However, the widely distributed European snails as well as the Balkan and Mediterranean species are much less important (Fig. 4). The assemblage with Bythinella austriaca is the characteristic association occurring in the Subatlantic Phase sediments (Fig. 6). The faunas with very great proportions of Bythinella austriaca are typical of calcareous tufas deposited in the Carpathians over several of the most recent centuries. A number of locations with such sediments were described in the area of the Pieniny Mts. (S.W. Alexandrowicz 1993, W.P. Alexandrowicz 2004, 2010, 2013c, 2014, W.P. Alexandrowicz et al. 2016), as well as in the Podhale Basin (W.P. Alexandrowicz 1997, 2001, 2003, 2004, W.P. Alexandrowicz \& Rybska 2013, W.P. Alexandrowicz et al. 2014) and the Beskidy Mts. (W.P. Alexandrowicz 2004, 2009) (Tab. 2). Similar assemblages have been also found in the Late Holocene sediments in other European countries (e.g., Horsák \& Hájek 2003, Cantonati et al. 2006, Georgopoulou et al. 2016) (Tab. 2).

\section{Environmental changes}

The rich and diversified assemblages of molluscs occurring in calcareous tufas within the Ociemny Stream valley enables the reconstruction of environmental changes during the deposition of sediments. The oldest fauna, representing the Early Holocene, occurs in the floor loams, and its composition and structure corresponds clearly to the assemblage with Discus ruderatus, which is typical of this period. At that time, a cool climate prevailed, helping the survival of cold-tolerant species typical of the Late Glacial (e.g., Columella columella, Vertigo genesii, Vertigo geyeri, and Semilimax kutulae). These forms can be considered to be glacial relics, and their presence in the sediments of Early Holocene has been noted in many locations within the Carpathians (Limondin-Lozouet 1992, W.P. Alexandrowicz 1997, 2001, 2003, 2004, 2013b, 2014, Sümegi \& Krolopp 2002, Schenkova et al. 2012, Schenkova \& Horsák 2013, W.P. Alexandrowicz et al. 2014, 2016) (Fig. 6). The predominant vegetation formations were forests with a major proportion of coniferous trees. At the end of Early Holocene or at the beginning of Middle Holocene, the erosion phase is distinct, displayed as an exposed erosion surface overlaid by a sand layer, with gravels, devoid of molluscan shells. The intensification of fluvial processes in this period has been described in many locations in the Carpathians (e.g. Starkel 1977, 1986, RalskaJasiewiczowa \& Starkel 1988, Starkel et al. 2006). This period is also associated with the phase of landslide formations (S.W. Alexandrowicz 1997, 
Margielewski 1998). The climate warming associated with a change in atmospheric circulation and the increased importance of humid and warmed oceanic air masses, marked during the Atlantic Phase (Ralska-Jasiewiczowa \& Starkel 1988), created the conditions favouring the sedimentation of calcareous tufas (Ložek 1964, Pazdur et al. 1988a, 1988b, Pedley 1990, 2009, Goudie et al. 1993, Pentecost 1995). During that time, calcareous tufas were formed, containing a very rich assemblage (with Discus perspectives) with a high proportion of shade-loving species (Fig. 6). It indicates fairly shadowed forest habitats, associated with mixed forests with a major proportion of deciduous trees having high environmental requirements. The subsequent phase of erosion occurs towards the end of the Atlantic Phase or at the beginning of Subboreal Phase. It is associated with climate cooling and the intensification of fluvial processes (Starkel 1986, Ralska-Jasiewiczowa \& Starkel 1988, Starkel et al. 2006). Also associated with this period is the slowing down or stopping of sedimentation, commonly observed in the Carpathians (Ložek 1964, Jäger \& Ložek 1968, Pazdur et al. 1988a, 1988b, W.P. Alexandrowicz 2004). In the Ociemny Stream valley, this phase corresponds to the higher sand band with cobblestones as well as a sedimentation gap covering the whole Subboreal Phase and the lower part of the Subatlantic Phase (Fig. 6). The roof part of the profile, including the sequence of calcareous tufas containing the assemblage with Bythinella austri$a c a$, has emerged during the several most recent centuries. This period is associated with the increase in the intensity of the carbonate sediments (Horsák \& Hájek 2003, W.P. Alexandrowicz 2004, 2009, 2010, 2014, Horsák et al. 2006) (Fig. 6). In the period of written history, the valley of the Ociemny Stream has not been subjected to strong anthropogenic pressure, has not undergone deforestation.

\section{CONCLUSIONS}

The profile of malacofauna-rich calcareous tufas in the Ociemny Stream valley, presented above, represents the sequence typical of the Holocene. The vast majority of the Quaternary locations of malacoenoses in the Pieniny Mountains covers much shorter time range, most often limited only to the Subatlantic Phase (W.P. Alexandrowicz et al. 2016). This fact decides about the unique nature of the location. Both the fauna analysis and the observations of the forms of sediments which build the profile point at the existence of some stratigraphic gaps within it. Sometimes the gaps span over fairly long periods of time. They correspond to the periods of intensified erosion which can be correlated with the phases of humidified climate during the Holocene. The malacological sequence shows a characteristic succession of assemblages indicating the progressive warming of the climate, leading to essential changes in vegetation cover and resulting in the principal modification of species composition, as well as ecological and zoogeographical structures of the molluscan assemblages. The transition from coniferous forests, typical of the Early Holocene, to the mixed and deciduous forests, typical of the middle part of the period, is evidently marked. A similar sequence has been described in numerous malacological locations, particularly in the neighbouring Podhale Basin (W.P. Alexandrowicz 1997, 2001, 2003, 2004, W.P. Alexandrowicz \& Rybska 2013, W.P. Alexandrowicz et al. 2014) and also in profiles in the Orawa peat bogs (Obidowicz 1991). In the tufas of the Ociemny Stream, no anthropogenic deforestation, whose principal phase in the area falls in the period of intensified settlement activity in the Middle Ages, is pronounced (W.P. Alexandrowicz 2013a, 2014, W.P. Alexandrowicz et al. 2014, 2016). It may perhaps be linked to the shape of the stream valley. In the Pieniny Mountains, similarly as with the Podhale Basin, the anthropogenic impact pertained chiefly to the sites with less diverse relief. Narrow valleys with steep slopes offered conditions disadvantageous to the development of human economic activities. Owing to that, they avoided the deforestation and retained their natural features.

\section{REFERENCES}

Alexandrowicz S.W., 1993. Late Quaternary landslides at eastern periphery of the National Park of the Pieniny Mountains, Carpathians, Poland. Studia Geologica Polonica, 192, 209-225.

Alexandrowicz S.W., 1996. Malakofauna i wiek osuwiska pod Czajakową Skałą w Wąwozie Homole. Chrońmy Przyrodę Ojczystą, 52, 45-54. 
Alexandrowicz S.W., 1997. Holocene dated landslides in the Polish Carpathians. [in:] Frenzel B. (ed.), Rapid mass movement as a source of climatic evidence for the Holocene, Palaeoclimate Research, 19, 75-83, Gustav Fischer Verlag, Studgart - Jena - Lübeck - Ulm.

Alexandrowicz S.W. \& Alexandrowicz W.P., 2011. Analiza malakologiczna. Metody badań $i$ interpretacji. Rozprawy Wydziału Przyrodniczego PAU, 3, Polska Akademia Umiejętności, Kraków.

Alexandrowicz S.W. \& Alexandrowicz Z., 1999. Recurrent Holocene landslides: a case study of the Krynica landslide in the Polish Carpathians. The Holocene, 9, 91-99.

Alexandrowicz W.P., 1997. Malakofauna osadów czwartorzędowych i zmiany środowiska naturalnego Podhala w młodszym vistulianie i holocenie. Folia Quaternaria, $68,7-132$.

Alexandrowicz W.P., 2001. Late Vistulian and Holocene molluscan assemblages from calcareous tufa at Ostrysz Hill (Podhale Basin). Folia Malacologica, 9, 159-169.

Alexandrowicz W.P., 2003. Odsłonięcie martwic wapiennych w Gliczarowie na Podhalu. Chrońmy Przyrodę Ojczysta, 59, 17-32.

Alexandrowicz W.P., 2004. Molluscan assemblages of Late Glacial and Holocene calcareous tufas in Southern Poland. Folia Quaternaria, 75, 1-309.

Alexandrowicz W.P., 2009. Malakofauna górnoholoceńskich martwic wapiennych $\mathrm{w}$ Beskidach Zachodnich (południowa Polska). Geologia: kwartalnik Akademii Górniczo-Hutniczej im. Stanisława Staszica w Krakowie, 35, 175-200.

Alexandrowicz W.P., 2010. Molluscan assemblages of recent calcareous tufas in the Podhale Basin and Pieniny Mts (S. Poland). Folia Malacologica, 18, 99-112.

Alexandrowicz W.P., 2013a. Molluscan communities in Late Holocene fluvial deposits as an indicator of human activity: A study in Podhale basin in South Poland. Ekológia (Bratislava), 32, 111-125.

Alexandrowicz W.P., 2013b. Malacological sequence from profile of calcareous tufa in Groń (Podhale Basin, southern Poland) as an indicator of the Late Glacial/Holocene boundary. Quaternary International, 293, 196-206.

Alexandrowicz W.P., 2013c. Molluscan assemblages in the deposits of landslide dammed lakes as indicators of late Holocene mass movements in the Polish Carpathians. Geomorphology, 180-181, 10-23.

Alexandrowicz W.P., 2014. Molluscan assemblages in Late Holocene tufa cones in the Pieniny Mountains (southern Poland). Geological Quarterly, 58, 269-280.

Alexandrowicz W.P., 2015. The application of malacological analysis in the study of slope deposits: Late Pleistocene and Holocene of the Podhale Basin (Carpathians, Poland). Acta Geologica Polonica, 65, 245-261.

Alexandrowicz W.P. \& Rybska E., 2013. Environmental changes of intramontane basins derived from malacological analysis of profile of Calcareous tufa in Niedzica (Podhale Basin, Southern Poland). Carpathian Journal of Earth and Environmental Sciences, 8, 13-26.

Alexandrowicz W.P., Szymanek M. \& Rybska E., 2014. Changes to the environment of intramontane basins in the light of malacological research of calcareous tufa: Podhale Basin (Carpathians, Southern Poland). Quaternary International, 353, 250-265.
Alexandrowicz W.P., Szymanek M. \& Rybska E., 2016. Molluscan assemblages from Holocene calcareous tufa and their significance for palaeoenvironmental reconstructions. A study in the Pieniny Mountains (Carpathians, southern Poland). Carpathian Journal of Earth and Environmental Sciences, 11, 37-54.

Birkenmajer K., 1977. Jurassic and Cretaceous lithostratigraphic units of the Pieniny Klippen Belt. Studia Geologica Polonica, 45, 1-158.

Cantonati, M., Gerecke R. \& Bertuzzi E., 2006. Springs of the Alps: sensitive ecosystems to environmental change: from biodiversity assessments to long-term studies. $\mathrm{Hy}$ drobiologia, 562, 59-96

Chafetz H.S. \& Folk R.L., 1984. Travertines: depositional morphology and the bacterially controlled constituents. Journal of Sedimentary Petrology, 54, 289-316.

Dehm R., 1967. Die landschnecke Discus ruderatus im Postglazial Sddeutschlands. Mitteilungen der Bayerische Staatssammlung für Paläontologie und Historische Geologie, 7, 135-155.

Dehm R., 1987. Die landschnecke Discus perspectivus im Postglazial Südbayerns. Mitteilungen der Bayerische Staatssammlung für Paläontologie und Historische Geologie, 27, 21-30.

Füköh L., 1993. Holocene malacofaunal assemblages in Hungary. Scripta Geologica, Special Issue, 2, 121-125.

Füköh L., 1995. History of the Hungarian Holocene mollusc fauna. Geojournal, 36, 255-259.

Gedda B., 2001. Environmental and climatic aspects of the Early and Mid Holocene calcareous tufa and land mollusc fauna in southern Sweden. Lundqua Thesis, 45, $1-50$.

Gedda B., 2006. Terrestrial mollusc succession and stratigraphy of a Holocene calcareous tufa deposit from the Fyledalen valley, southern Sweden. The Holocene, 16, 137-147.

Goudie A.S, Viles H.A. \& Pentecost A., 1993. The late-Holocene tufa decline in Europe. The Holocene, 3, 181-186.

Georgopoulou E., Neubauer T.A., Strona G., Kroh A., Mandic O. \& Harzhauser M., 2016. Beginning of a new age: How did freshwater gastropods respond to the Quaternary climate change in Europe? Quaternary Science Reviews, 149, 269-278.

Hammer Ø., Harper D.A.T. \& Ryan P.D., 2001. Past: paleontological statistics software package for education and data analysis. Palaeontologica Electronica, 4, 1-9.

Horáčková J., Ložek V. \& Juřičková L., 2015. List of malacologically treated Holocene sites with brief review of palaeomalacological research in the Czech and Slovak Republics. Quaternary International, 357, 207-211.

Horsák M. \& Hájek M., 2003. Composition and species richness of molluscan communities in relation to vegetation and water chemistry in the Western Carpathian spring fans: the poor-rich gradient. Journal of Molluscan Studies, 69, 349-357.

Horsák M., Hájek M., Dítě D. \& Tichy L., 2006. Modern distribution patterns of snails and plants in the western Carpathian spring fens: is it a result of historical development? Journal of Molluscan Studies, 73, 53-60.

Jäger K.D. \& Ložek V., 1968. Beobachtungen zur Geschichte der Karbonatdynamik in der Holozän Warmzeit. Československy Kras, 19, 7-20. 
Juřičková L., Horsák M., Horáčková J., Abrhám V. \& Ložek V., 2014. Pattern of land-snail succession in Central Europe over the 15,000 years: Man changes along environmental, spatial and temporal gradients. Quaternary Science Reviews, 93, 155-166

Ložek V., 1964. Quartärmollusken der Tschechoslowakei. Rozpravy Ustředniho Ustavu Geologického, 31, 1-374.

Limondin-Lozouet N., 1992. Biogéographie Holocène de Vertiginidae (mollusca: gastropoda) Européens: relations la dernière déglaciation. Compest Rendus de l'Académie des Sciences Paris, 315, 1281-1287.

Limondin-Lozouet N., 2011. Successions malacologiques à la chamière Glaciaire/Interglaciaire: du modèle Tardiglaciaire-Holocene aux transitions du Pleistocène. Quaternarie, 22, 211-220.

Limondin-Lozouet N. \& Preece R.C., 2004. Molluscan successions from the Holocene tufa of St Germain-le-Vasson, Normandy (France) and their biogeographical significance. Journal of Quaternary Science, 19, 55-71.

Margielewski W., 1998. Landslide phases in the Polish Outer Carpathians and their relation to climatic changes in the Late Glacial and the Holocene. Quaternary Studies in Poland, 15, 37-53.

Meyrick R.A., 2002. Holocene molluscan faunal history and environmental change at Kloster Mühle, RheinlandPfalz, western Germany. Journal of Quaternary Science, $18,121-132$.

Morisita M., 1959. Measuring of interspecific association and similarity between communities. Memories of the Faculty of Sciences, Kyushu University, E, 3, 65-80.

Obidowicz A., 1990. Eine pollenanalytische und moorkundlische Studie zur Vegetationgeschichte des Podhale-Gebietes (West-Karpaten). Acta Palaeobotanica, 30, 147-219.

Pazdur A., Pazdur M.F. \& Szulc J., 1988a. Radiocarbon dating of Holocene calcareous tufa from south Poland. Radiocarbon, 30, 133-146.

Pazdur A., Pazdur M.F., Starkel L. \& Szulc J., 1988b. Stable isotopes of the Holocene calcareous tufa in southern Poland as palaeoclimatic indicators. Quaternary Research, 30, 177-189.

Pedley H.M., 1990. Classification and environmental models of cool freshwater tufas. Sedimentary Geology, 68, 143-154.
Pedley H.M., 2009. Tufas and travertines of the Mediterranean region: a testing ground for freshwater carbonate concepts and developments. Sedimentology, 56, 221-246.

Pentecost A., 1995. The Quaternary travertine deposits of Europe and Asia Minor. Quaternary Science Reviews, 14, 1005-1028.

Pielou E.C., 1975. Ecological diversity. John Wiley \& Sons, New York.

Pokryszko B., 1991. The Vertiginidae of Poland (Gastropoda: Pulmonata: Pupillidae) - a systematic monograph. Annales Zoologici, 43, 8, 133-257.

Preece R.C. \& Day S.P., 1994. Comparison of Post-glacial molluscan and vegetational successions from a radiocarbon-dated tufa sequence in Oxfordshire. Journal of Biogeography, 21, 463-468.

Ralska-Jasiewiczowa M. \& Starkel L., 1988. Record of the hydrological changes during the Holocene in the lake, mire and fluvial deposits of Poland. Folia Quaternaria, 57, 91-127.

Schenkova V. \& Horsák M., 2013. Refugial populations of Vertigo lilljeborgi and V. genesii (Vertiginidae): new isolated occurrences in Central Europe, ecology and distribution. American Malacological Bulletin, 31, 323-329. Schenková V., Horsák M., Plesková Z. \& Pawlikowski P., 2012. Habitat preferences and conservation of Vertigo geyeri (Gastropoda: Pulmonata) in Slovakia and Poland. Journal of Molluscan Studies, 78, 105-111.

Shannon C. E. \& Weaver W., 1949. The mathematical theory of communication. University of Illinois Press, Urbana.

Starkel L., 1977. Paleogeografia holocenu. Państwowe Wydawnictwo Naukowe, Warszawa.

Starkel L., 1986. Holocene climatic changes reflected in the slope and valley floor evolution in European mountains. Studia Geomorphologica Carpatho-Balcanica, 20, 49-57.

Starkel L., Soja R. \& Michczyńska D.J., 2006. Past hydrological events reflected in Holocene history of Polish Rivers. Catena, 66, 24-33.

Sümegi P. \& Krolopp E., 2002. Quatermalacological analyses for modeling of the Upper Weichselian palaeoenvironmental changes in the Carpathian Basin. Quaternary International, 91, 53-63.

Žak K., Ložek V., Kadlec J., Hladikova J. \& Cilek V., 2002. Climate-inducted changes in Holocene calcareous tufa formations, Bohemian Karst, Czech Republic. Quaternary International, 91, 137-152. 